\title{
IHAB HASSAN POSTMODERNISM'S INDETERMINACY AND IRONY:LAURA BROWN'S INNER CONFLICT IN THE HOURS
}

\author{
${ }^{1}$ Rina Wahyu Setyaningrum* \\ ${ }^{1}$ Universitas Muhammadiyah Malang, Indonesia \\ *Corresponding Author:rina@umm.ac.id
}

\begin{abstract}
Virginia Woolf is one of the modernist writers who write Mrs. Dalloway for which Michael Cunningham has taken Virginia's life story into his novel, The Hours that characterized Laura Brown who reads Mrs. Dalloway. Cunningham's literary work which foregrounds the uncertainty of sexual orientation, confusion, and difficulty of identity is suitable with postmodernism's conventions and is valid in both Woolf's and Cunningham's novels. There have been studies conducted by the scholars in terms of various technical aspects, such as narrative, design, and structure. The other topics comprise the equivalence of characters, the parallelism of scenes, and the borrowing of themes and symbolism, in order to demonstrate the effects of the adaptation process. This paper focuses on Laura Brown's inner conflicts which are connected to postmodernism features. From the quotations in the novel, this paper showcases the novel's analysis based on Ihab Hassan's theory of postmodernism's indeterminacy and irony. It is found that Laura Brown's inner conflicts are shown from her efforts of being a good wife for Dan. She is trying hard to answer her own question whether or not she loves her husband. Ironically, the perfect status of being a wife of a soldier who takes part in winning the World War II, a woman with a perfect family, as well as a woman living a good life, do not make her happy. Mrs. Dalloway has inspired her to find her true happiness, her former self that has disappeared.
\end{abstract}

Keywords: Indeterminacy; Inner Conflict; Irony

\begin{abstract}
ABSTRAK
Virginia Woolf adalah salah satu penulis modernis yang menulis Mrs. Dalloway, dan Michael Cunningham mengisahkan kehidupan Virginia ke dalam novelnya, The Hours, dengan menampilkan karakter Laura Brown yang membaca Mrs. Dalloway. Novel karya Cunningham ini mengedepankan ketidakpastian orientasi seksual, kebingungan, dan kesulitan identitas, seperti yang dijelaskan dalam konvensi postmodernisme. Posmodernisme tampak jelas pada kedua novel baik yang ditulis oleh Woolf maupun Cunningham. Pada beberapa kajian terdahulu, aspek yang diteliti dari novel Cunningham meliputi aspek teknis, seperti narasi, desain, dan struktur. Selain itu, topik lain yang diteliti diantaranya persamaan tokoh, kesejajaran adegan, dan adaptasi tema serta simbolisme. Artikel ini fokus pada konflik batin Laura Brown yang dikaitkan dengan postmodernisme. Dari kutipan yang ada dalam novel, analisis dilakukan sesuai dengan teori ketidakpastian dan ironi dalam postmodernisme yang dicetuskan Ihab Hassan. Hasilnya, diketahui bahwa konflik batin Laura Brown ditunjukkan dari upayanya untuk menjadi istri yang baik bagi Dan. Dia berusaha keras untuk menjawab pertanyaannya sendiri apakah benar dia mencintai suaminya. Ironisnya, status sempurna sebagai istri seorang prajurit yang ikut memenangkan perang dunia II, wanita dengan keluarga yang sempurna, serta wanita yang menjalani kehidupan yang baik, tidak membuatnya bahagia. Dibandingkan dengan Mrs. Dalloway, Laura masih lebih beruntung karena dia masih memiliki pilihan antara hidup atau mati. Dia pun memilih untuk melanjutkan kehidupannya dan keluar dari segala bentuk konflik batin yang ada. Baginya, Mrs. Dalloway telah menginspirasi dirinya untuk menemukan kebahagiaan sejatinya, yang dulu pernah hilang.
\end{abstract}


Kata Kunci: Ironi; Ketidakpastian; Konflik Batin

\section{INTRODUCTION}

There have been numbers of studies about Cunningham's The Hours that exposed bodies of his characters and the role the body plays in the world of the mind, the personality, the soul, and the very actions of his characters (Erickson, 2001). Inspired by the Virginia Woolf's Mrs. Dalloway, The Hours is a novel exposing sexual identity (Schiff, 2004).As a mutation literary work, Cunningham has adapted the previous novel as the leap from modernism to postmodernism (Hardy, 2011). One of the characteristics of postmodernism is the ruling of power which is realized by giving the voice of women for equality.

The Hours has been studied from its different points of view. Erickson (2011) analyzed Cunningham's work The Hours that has three distinct but resounding story lines. First of all, there was the very plausible character of Mrs. Woolf herself, who wrote Mrs. Dalloway while living outside London in Richmond with her husband Leonard. Then there was the contemporary Clarissa, called "Mrs. Dalloway" by her AIDS-stricken poet and friend, Richard, and last of all Mrs. Laura Brown, who was pregnant for the second time and caring for her little son on her husband's birthday. As a mode of transmission of the mystery and beauty of life, Hughes (2004) criticized The Hours as a representative of at least one type of postmodern art that reflects earlier art, then scholars must consider one final aspect of this model: the concept that the reaction of the reader (in the case of literature) is central to the infinite phase in which art participates. Furthermore, Hardy (2011)viewed this literary work from identity because of the fact that fictional characters are built not only differently from Woolf's, but differently from each other. Related to modern fiction, Jiménez (2020)appraised that The Hours' thematic and aesthetic concerns clearly shows Cunningham's work that presents the characteristics of postmodernism practice.

Postmodern literature is a genre of literature characterized, both stylistic and theoretical, by the reliance on such literary conventions as fragmentation, paradox, inconsistent narratives, frequently unrealistic and entirely impossible plots, games, satire, paranoia, dark humor and authorial self-reference. It has tended to be focused on one kind of writing -Narrative Fiction. Postmodernism is frequently described as dealing a death-blow to sociology. Butler (2002) claimed that one of the literary works, the postmodernist novel, does not attempt to create a sustained realist illusion. It presents itself as accessible to all the illusory tricks of stereotyping and narrative manipulation, and to multiple interpretations. Its contradictions and inconsistencies are fundamental to postmodernist thinking. In addition, Nicol (2009) affirmed that postmodern fiction attracts the readers to be active co-creators of meaning to deepen the readers' knowledge about literature in a wider scale. This literary work always exposes the conflict - men as source of problems.In essence, Doyle (2018) clarified the deconstructive ideas of postmodern literature have effectively subverted the neoliberal hypocrisy of previous decades. It is closely related to what has been identified by Timmer (2010)that the postmodern situation is related to what makes it difficult to be a human being and values empathy and interpersonal relationships. 
Ihab Hassan's term of postmodernism isfamous as all literary works published from 1960s to 1980s referred to his work (Bertens, 1995). Instead of giving a definition of postmodernism, Hassan (1985) argued that constant negotiations, perpetual transactions of desire, freedom, and justice should be the culture of postmodernism. Furthermore, related to pluralism in postmodern perspective, Hassan (1986) offered eleven features to make it easier for us in understanding this thought. They are indeterminacy, fragmentation, decanonization, self-less-ness, the unpresentable, irony, hybridization, carnivalization, performance, constructionism, and immanence.

Related to the internal conflicts experienced by the three women in the story, Laura Brown's life is the most interesting because of the influence of Mrs. Dalloway that she reads. Reading it, she is comparing her life to Mrs. Dalloway's which causes her internal conflicts. Inaccordance, this writing applies only two features; indeterminacy and irony. Indeterminacy feature relates to the whole way of ambiguities, ruptures, and displacements that affect knowledge and society. Indeterminacy pervades how people act, how they perceive an idea, and how they interpret it. Hassan (1993) described indeterminacy as a complex referent that covers diverse concepts such as ambiguity, discontinuity, heterodoxy, pluralism, randomness, revolt, perversion, and deformation. In short, indeterminacy refers to the uncertainty of life when it is beyond people's power to decide what is best for them.

Meanwhile, Irony, which is also called as perspectivismas it sees that postmodern literature gives the audience the freedom to utilize their own judgment based on their perspective and interpretation. Nicol(2009) narrated that postmodern mentality is always satirical. Adetuyi \& Patrick(2019) that satire as a literary device can be found in popular culture of many works containing of criticism. When there is no cardinal principle, the people might turn their literary works into irony. The feature of irony considers indeterminacy as something multivalent or having many values, meaning, or appeals. Doyle (2018)construed that by means of techniques such as deconstruction and irony, postmodern literature has rejected ideals such as reality and meaning as delusions, practicing a continuous process of problematicization or subversion of realistic (mainstream) aesthetic ideology. Therefore, in contrast with the character's expectation, something happens as a discretion. This article aims at spotlighting Laura Brown's struggles to combat her inner conflicts and analyzing it using Ihab Hassan's indeterminacy and irony of postmodernism.

\section{METHOD}

In studying this literary work, The Hours novel is the object from which the data of Laura Brown's internal conflicts are analyzed using Ihab Hassan's indeterminacy and Irony postmodernism features(Hassan, 1986). Secondary sources, such as prior studies on the postmodernism literature and The Hours novel, journal's articles, and books related to the subject being investigated are also taken into account. The data are qualitative in nature. Textual analysis is done in forms of words, phrase, or sentences quoted from the novel. By multiple close-reading in order to understand the novel, some important information is identified, classified, analyzed, and described for drawing the conclusions. Moreover, to achieve the goal of this study, the theoretical framework of postmodernism is used as guidance. 


\section{FINDINGS}

The story of Laura Brown is the representation of a common middle-class family during the 1950s in the United States. Being married to her little brother's best friend, Laura feels like an older sister to Dan. The reasons why she married Dan is because of her responsibility as Dan has fought for the country in World War II and saved the world. Laura's difficulties in getting through her life attracts the readers' sympathy as Cunningham uses indirect internal monologue(Schiff, 2012). One of those he perfectly shows is Laura's emotional process and thoughts towards the events when she is unconfident in doing her domestic tasks as a housewife as well as a mother.

\section{Laura Brown's Inner Conflicts}

Set in Los Angeles, the Browns family consists of Laura, her husband Dan, and her son Richie. Each of those three has common social roles: wife-mother, husband, and child. As a father and husband, Dan has a complete life; he is a world war-hero, has a good occupation, lives in a nice house with two lavish cars on its driveway, and has a lovely son and a beautiful pregnant wife. In short, the Brown family seemingly lived a perfect life post the World War. However, Laura feels the emptiness of her life. Deep inside her heart, she feels frustrated, particularly about her social roles as a wife who is also a mother expecting her second child while at the same moment she starts to question her feelings for Dan.

\section{Indeterminacy}

The question of her love for Dan makes her suffer during the day of Dan's birthday. She tries to ensure herself that she still loves Dan no matter what her heart says by making a birthday cake and preparing a party for him. By doing these two efforts, she forces herself to be a good wife when her inner-self rejects this role. With help from Richie, she makes the cake with uneasiness. The little boy feels the strange behaviors of his mother, yet he could not do anything as he is too young to understand the complexity of the adult's feelings. As a child, Richie tries to cheer his mother up but he fails. The following quotation explains her feeling.

She thinks of the gifts she's bought her husband; the gifts he will appreciate, even cherish, but which he does not in any way want. Why did she marry him? She married him out of love. She married him out of guilt; out of fear of being alone; out of patriotism. He was simply too good, too kind, too earnest, too sweet-smelling not to marry. He had suffered so much. He wanted her.(Cunningham, 1998: p.104)

After they finish making the cake, Kitty, one of their neighbors, comes in. Kitty is about to visit a hospital for some medical treatments for some days due to her health problem. She asks Laura to feed her dog when she is away. Both women have quite a similar role as the wife of successful men. Just like Laura, it seems Kitty also questions her feelings for her husband. When Kitty shares her story about her health and her problems with her husband, in an unexpected move, Kitty and Laura share a romantic kiss. Kitty 's anxiety and Laura's caring sympathy soon led to an unexpected moment of intimacy 
Celtic: A Journal of Culture, English Language Teaching, Literature and Linguistics

Vol. 7, No. 2, December 2020.

E-ISSN: 2621-9158 P-ISSN:2356-0401

http://ejournal.umm.ac.id/index.php/celtic/index

between the two women. Laura wraps Kitty up in an embrace, and after a few seconds, Kitty turns her face up to Laura's face. The evidence is as follows.

Kitty lifts her face, and their lips touch. They both know what they are doing. They rest their mouths, each on the other. They touch their lips together, but do not quite kiss. It is Kitty who pulls away. "You're sweet,' she says.(Cunningham, 1998: p.110)

It is awkward for both of them as they later are aware that Richie sees them kissing. Richie, who seemingly is too young to understand lust, seems to see nothing wrong with his mother and his neighbor's doings. However, driven by the guilty feeling of cheating, both women act awkwardly. After Kitty leaving, Laura throws away the birthday cake to the trash bin. This could be an indication that the kiss makes her convince herself that the feeling she once had for Dan might not be longer there.

After that, she brings Richie out and leaves him at her friend's house. Feeling afraid of being left behind, Richie cries when Laura leaves him but she does not care. She is about to spend the time alone in a luxurious hotel while reading a novel Mrs. Dalloway written by Virginia Woolf, a celebrated literary figure who holds a significant role in this novel.This is then inspiring her to do similar things like what Mrs. Dalloway is doing. The following quotation is the proof.

It seems, somehow, that she has left her own world and entered the realm of the book. Nothing, of course, could be further from Mrs. Dalloway's London than this turquoise hotel room, and yet she imagines that Virginia Woolf herself, the drowned woman, the genius, might in death inhabit a place not unlike this one... Having this room to herself seems both prim and whorish. She is safe here. She could do anything she wanted to, anything at all. (Cunningham, 1998: p.150)

The general plot of the novel is about the life of Mrs. Dalloway who shares quite similar life with Laura; both are the wife of respectable men and they question their role and sexuality. At that moment, she seriously contemplates killing herself by taking sleeping pills. It seems that she already takes some pills when she hallucinates being drowned in the water and wakes up. After waking up, she feels that killing herself might not be a good choice. Then she picks up Richie and drives back home.

Arrived at home, she makes another new birthday cake for her husband. On that day, she surrenders to the standards of the normal wife. Later, she abandons her family to move to Canada and works a librarian. This decision gives a terrible pain to her family, especially to Richie which later inspires his tragic poems -and his tragic life. However, her decision also hurts herself as she has to live with the guilty feeling for the rest of her life. When Richie kills himself at the end of the story, Laura comes and shows her regret.

\section{Irony}

Living in the era of post-World War II, Laura Brown could be the image of a perfect woman. First, she is lucky that she is a citizen of the country that wins the war. 
The same inner conflict could happen to a German woman who marries a soldier. However, as a citizen of losing country wrecked by a lengthy war, this German lady might never have any time and energy to question her love for her husband. Even she would not have any chance to make a birthday cake or to prepare for a birthday party. Or worse, she could never have any chance to meet her husband again that was killed in action or caught as a prisoner of war. Another perk of being a citizen of the winning country is that she and her family could enjoy the good economy that provides her roof, food, money, and cars. Should she lived in the losing country, she would never have the luxury of leisure time to read novels or to wander her mind as she would need to work hard just to stay alive. The following evidence is quoted from the novel.

In another world, she might have spent her whole life reading. But in the new world, she rescues world - there's not much room for idleness. So much has been risked and lost; so many have died. Less than five years ago Dan himself was believed to have died, at Anzio, and when he was revealed two days later to be alive after all (he and some poor boy from Arcadia had had the same name), it seemed he had been resurrected. He seemed to have returned, still sweet-tempered, still smelling like himself, from the realm of the dead (the stories you heard then about Italy, about Saipan and Okinawa, about Japanese mothers who killed their children and themselves rather than be taken prisoner), and when he came back to California he was received as something more than an ordinary hero. (Cunningham, 1998: pp. 39-40)

Second, she could be said as a perfect woman as she has a perfect family. Her husband loves her and her son admires her. Yet, it is inevitable for her to question her feelings for her family. It is inevitable because when she goes back home from the hotel after the failed suicide attempt, she struggles to reject her own feeling as she tries again to be a good wife shown by her effort to make a new birthday cake, and still she finally leaves her family to Canada. Her indeterminacy to revolt against the marriage makes her do what she does. It is also her indeterminacy that works when she kisses Kitty in such a random move. It is also ironic when she accidentally cheats on her husband with a kiss with another person on his birthday. The following quotation is evidenced the ironic story.

She touches her lips, where Kitty's kiss briefly resided. She doesn't mind so much about the kiss, what it does and does not imply, except that it gives Kitty an edge. Love is deep, a mystery - who wants to understand its every particular? Laura desires Kitty. She desires her force, her brisk, and cheerful disappointment, the shifting pink-gold lights of her secret self and the crisp, shampooed depths of her hair. Laura desires Dan, too...She can kiss Kitty in the kitchen and love her husband, too.(Cunningham, 1998: p. 143)

Third, she lives a good life. She has a nice house in an expensive area, her husband works a good occupation, and she drives her own car. However, she chooses to 
Celtic: A Journal of Culture, English Language Teaching, Literature and Linguistics

Vol. 7, No. 2, December 2020.

E-ISSN: 2621-9158 P-ISSN:2356-0401

http://ejournal.umm.ac.id/index.php/celtic/index

abandon all those good things. Her initial effort is when she tries to kill herself and the second one when she moves to Canada working as a librarian. If she stays in his marriage life, she does not need to work for life. She just needs to obey the normal standards of a good wife and everything would be just fine. Yet, she chooses to leave it all behind to live a new life that she thinks suits her better. The proof is as follows.

She returns to the living room, to Laura Brown. Laura smiles wanly at Clarissa - who could possibly know what she thinks or feels? Here she is, then; the woman of wrath and sorrow, of pathos, of dazzling charm; the woman in love with death; the victim and torturer who haunted Richard's work. Here, right here in this room, is the beloved; the traitor. Here is an old woman, a retired librarian from Toronto, wearing old woman's shoes. (Cunningham, 1998: p. 226)

All her attempts to make everything remains fine always ends with her effort to kill herself because of her the guilt and pressure in her life.Itis ironic that she determines not to kill herself because it would hurt her family. The following quotation helps explain it.

So Laura Brown, the woman who tried to die and failed at it, the woman who fled her family, is alive when all the others, all those who struggled to survive in her wake, have passed away. She is alive now, after her exhusband has been carried off by liver cancer, after her daughter has been killed by a drunk driver. She is alive after Richard has jumped from a window onto a bed of broken glass.(Cunningham, 1998: p.222)

This is the evidence why Laura Brown's behavior is always interesting to study. Cunningham has made the readers surprised of what is going to happen in Laura's life. Various perceptions might appear dealing with the life of a bookworm who is unhappy marrying a soldier who always considers his life a perfect one.

\section{DISCUSSION}

As it has been agreed that feminism is one of the issues related to postmodernism that its thinking and writing functions as the history or cultural setting in many text (Butler, 2002; Timmer, 2010), Laura Brown's inner conflict is realized by her gender or sexual identity. What she imagines is freedom, not being dominated by the family needs of taking care of everything, husband, son and second son to be. Her inner conflict arises because she is reading Mrs. Dalloway from which she knows that women should be equal to men. Taylor (1991)has reviewed that androgyny is central in Mrs. Dalloway's life. Additionally, Lamszuz(2019) elaborated Taylor's review that Laura Brown struggles with artistic anxiety for performing a house wife, like what has been characterized by Virginia Woolf in Mrs. Dalloway. Laura is struggling of feasible changes in her life by trying to be a good wife in managing Dan's birthday party and making his birthday cake. However, all of those make herself suffering. Her role as a wife that should be naturally practiced always makes her unhappy. Confusing about her life, Kitty's coming makes herself unable to stop her ambivalent behavior, a 
spontaneous instinct to kiss Kitty. This is what a postmodernism perspective proposed by Hassan (1993) as a indeterminacy. Hence, trying to find happiness and comfort by reading Mrs. Dalloway, she would like to move out of her life and objectively analyze her own experiences. The subject of suicide also causes her to accept the fact that she needs to find a way out of her own life. Lamszuz(2019)has analyzed Laura's efforts as a battle to suppress her previous interest and desires that she would find happiness to be Dan's wife.

Hughes (2004) considered The Hours as a postmodernism art that its movement opposes linearity. It does not follow the linear structure of beginning, middle, and end but the dialogue is carried on widening circles that requires understanding to reach its message. Two features of Hassan's idea of pluralism in postmodern perspectives have directed us to social, esthetic, and intellectual assumptions of postmodernism. It is evidenced that Laura's struggles in her life is unpredictable that she is reading Mrs. Dalloway for the sake of finding a way to confront her inner conflict. By using Hassan's indeterminacy feature of postmodernism (Hassan, 1986), there found Laura Brown's life uncertainty that in one hand she would like to leave her family, on the other hand, she does not want to make her family down. Hardy (2011) encountered that Laura craves isolation and freedom from oppressive mediocrity in The Hours have made the readers of the novel comprehend Laura's behaviors in constructing herself after reading Mrs. Dalloway.

Satirical evidences depicted from Laura Brown's life in this novel dominantly feature the perfection of Laura's life which should be on common women's imagination. Related to what has been explained by Nicol (2009) about the postmodern mentality, Hassan's irony featured within his postmodern perspectives is in line with Laura Brown's life. From the data stated in the findings, it is crystal clear that some might say her life is ironic that she feels empty when everything surrounding her is full of perfection. The latest analysis about Laura Brown's life written by Jiménez(2020) focused on the paradox of how fragmented Laura is, indeed, her world destabilization comes from the Mrs. Dalloway's pages that she reads.

\section{CONCLUSION}

Reading Virginia Woolf's writing which means learning a thing or two about her gender, woman emancipation, and sexuality has directed Laura Brown to learn those principles. She knows that there are other ideas beyond the standardized norms at that time. Different from Virginia Woolf that needs to commit suicide to free herself, Laura has more options. Shown by her statement "It was death; I choose life," Laura has the luxury to decide her own life. However, she suffers a guilty feeling when his family is broken into pieces after she leaves. The displacement and pain perceived by Richie from his family make him be an award-winning poet that when he grows up. If Laura keeps staying, no one knows whether Richie would be a good writer or a crooked criminal. 
Celtic: A Journal of Culture, English Language Teaching, Literature and Linguistics

Vol. 7, No. 2, December 2020.

E-ISSN: 2621-9158 P-ISSN:2356-0401

http://ejournal.umm.ac.id/index.php/celtic/index

\section{REFERENCES}

Adetuyi, C. A., \& Patrick, C. A. (2019). Analysis of Religious Satire in P'Bitek's Song of Lawino. CELTIC: A Journal of Culture, English Language Teaching, Literature \& Linguistics, 6(2), 33-41.https://doi.org/10.22219/celtic.v6i2.9929

Bertens, H. (1995). The Idea of the Postmodern: A History. In World Literature Today. https://doi.org/10.2307/40151833

Butler, C. (2002). Postmodernism : A Very Short Introduction. New York: Oxford University Press.

Cunningham, M. (1998). The Hours. New York: Picador USA.

Doyle, J. (2018). The changing face of post-postmodern fiction: Irony, sincerity, and populism. Critique: Studies in Contemporary Fiction, 59(3), 1-12. https://doi.org/10.1080/00111619.2017.1381069

Erickson, D. E. (2001). “The Upholstery of the Soul”: Michael Cunningham's The Hours . Christianity \& Literature, 50(4), 715-722. https://doi.org/10.1177/014833310105000410

Hardy, B. S. (2011). The unanchored self in the hours after Dalloway. Critique - Studies in Contemporary Fiction, 52(4), 400-411. https://doi.org/10.1080/00111610903401414

Hassan, I. (1985). The culture of postmodernism. Theory, Culture \& Society, 2(3), 119131. https://doi.org/10.1177/0263276485002003010

Hassan, I. (1986). Pluralism in Postmodern Perspective. Critical Inquiry, 12(3), 503520. https://doi.org/10.1086/448348

Hassan, I. (1993). Toward a Concept of Postmodernism. In J. Natoli \& L. Hutcheon (Eds.), A Postmodern Reading (pp. 1-10). New York: State University of New York Press.

Hughes, M. J. (2004). Michael Cunningham's The Hours and Postmodern Artistic RePresentation. Critique - Studies in Contemporary Fiction, 45(4), 349-361. https://doi.org/10.3200/CRIT.45.4.349-361

Jiménez, M. (2020). The Hours and the Nations: Virginia Woolf's Life and Art in Michael Cunningham's America. In M. Rensen \& C. Wiley (Eds.), Transnational Perspectives on Artists 'Lives (pp. 239-254). Cham, Switzerland: Palgrave Macmillan.

Lamszuz, E. (2019). Artistic Anxiety and the Pressure to Perform in Michael Cunningham 's The Hours. Humanities Bulletin, 2(2), 194-206.

Nicol, B. (2009). The Cambridge Introduction to Postmodern Fiction. Cambridge: Cambridge University Press.

Schiff, J. (2004). Rewriting woolf s Mrs. Dalloway: Homage, sexual identity, and the single-day novel by Cunningham, Lippincott, and Lanchester. Critique - Studies in Contemporary Fiction, 45(4), 363-382. https://doi.org/10.1080/00111619.2004.11644152

Schiff, J. (2012). Reading and writing on screen: Cinematic adaptations of McEwan's Atonement and Cunningham's the Hours. Critique - Studies in Contemporary Fiction, 53(2), 164-173. https://doi.org/10.1080/00111619.2012.641902

Taylor, N. (1991). Erasure of Definition: Androgyny in Mrs. Dalloway. Women's Studies, 18(4), 367-377. https://doi.org/10.1080/00497878.1991.9978843 
Setyaningrum, R.W. (2020). Ihab Hassan Postmodernism's Indeterminacy and Irony: Laura Brown's Inner Conflict in The Hours.Celtic: A Journal of Culture, English Language Teaching, Literature and Linguistics, 7(2), 173-182.

Timmer, N. (2010). Do You Feel It Too? The Post-Post Modern Syndrome in American Fiction at the Turn of the Millenium (T. D'haen \& H. Bertens, eds.). Amsterdam New York: Rodopi. 